\title{
Importing American racial reasoning to social science research in Sweden
}

\begin{abstract}
How does one research racial categorizations and exclusions while remaining sensitive to context? How does one engage the social reality of racial categorizations and the history of racialized exclusions without falling into the trap of race essentialism? These concerns prompt debate about, and also resistance to, examining race in Swedish social science. In this article, Voyer and Lund offer American racial reasoning as one possible approach to researching race in the Swedish context. American racial reasoning means being attentive to how power and the processes of social inequality operate through categories of racial and ethnic difference, and also seeing the path to greater equality in the embrace of those categories. American racial reasoning is a valuable research tool that uncovers dynamics of social inequality and possibilities for social justice that are otherwise difficult to grasp. Taking up the topic of immigration in Sweden, Voyer and Lund demonstrate the analytical value of American racial reasoning for understanding persistent social inequality and exclusion even when explicit racial categories are not in wide use in everyday life.
\end{abstract}

Keywords: Race, Racism, Discrimination, Racial Reasoning, Sweden, United States

CURRENT EVENTS POINT to some important work ahead for social scientists mainstreaming the consideration of race, racism, and racialized exclusions in our research, and fully accepting the premise that race is a social construction. At the time of this writing, there is ongoing social turmoil in Sweden and abroad, including demonstrations against structural racism, a global pandemic spreading more quickly and with larger death rates among racial, immigrant, and other minority populations, and the apparent capitulation of Sweden's mainstream political parties to xenophobic assaults on the rights to asylum and citizenship. Meanwhile, in Sweden there is an established research tradition documenting the discrimination and exclusion of some racialized groups and the corresponding privileges attached to white Swedishness (see for example Ålund 1985, 1988, 1997; Knocke 1986; Schierup \& Paulson 1994; Molina 1997; de los Reyes, Molina \& Mulinari 2002; Neergaard 2002; Lundström 2007;

1 Equal co-authors. 
Bursell 2012; Hübinette \& Lundström 2014, 2020; Hübinette 2017), but there is also resistance to taking up the topic of race in Swedish social science.

Everyone in Swedish society has work to do to address their part in the perpetuation of structural racism, and for social scientists that work includes incorporating a raciallyaware perspective in their research. Being racially-aware means making considerations of race and racial equality a necessary element of research, even when that research is not explicitly about race or racism. Racial awareness in research is similar to sex and gender awareness. Beginning in 2019, the Swedish Research Council began requiring that grant applications include a discussion of sex and gender perspectives that are relevant to the proposed research (Swedish Research Council 2019). If a researcher does not explicitly include considerations of sex and gender, they are asked to discuss why they chose not to do so. This requirement is intended to insure that all researchers, not just those who study sex or gender, consider the significance of gender for their research. Racially-aware perspectives should be expected as well.

Although racism, including the oppression of indigenous ethnic minority groups, has a long history in Sweden (Catomeris 2004; Pikkarainen \& Brodin 2008; Hübinette 2017), as Khayati (2017) notes, in contemporary times stigmatization and racism tend to operate through the division between "immigrants" and "Swedish." In the Swedish context, "immigrant" has a socially-constructed meaning that breaks from its typical definition: "most immigrants are Swedish-born persons" (Statistics Sweden 2019). "Immigrant" is therefore a category that incorporates social meanings beyond migration, including the underlying sense of "immigrant as a social problem" (Trondman 2006:434). As a result, unreflexive use of the category "immigrant" or "immigrant background" for research purposes risks adopting and reifying insider and outsider categories without interrogating them. When social scientists use a Muslim-sounding name as a measure of immigrant-ness, extend the definition of immigrant to include people with one parent or grandparent born abroad, or employ a measure of neighborhood segregation in the operationalization of the category immigrant, they formalize background cultural meanings. In contrast to stretching the concept of immigrant to include those to whom it should not apply, there is also a reluctance to apply the concept to those who do literally count as immigrants, as one of the authors of this article knows from direct experience as a white American who immigrated to Sweden for work and has been told repeatedly that she isn't an immigrant at all.

In Sweden, the idea of the immigrant is a racialized fantasy - an essentialized category of fundamental difference that has little to do with actually being an immigrant, and a whole lot to do with being non-white, non-Western, and/or Muslim. What are the chances for social integration and equality when one's skin, last name, or religious observance mark them as persistent outsiders who are not Swedish by definition? It's difficult to get a full view of the damage this racialized conception of the immigrant causes without first adopting a racially-aware perspective on Sweden in general. After all, how can we theorize and pursue immigrant integration without taking account of symbolic exclusion based upon a widely-shared belief in the distinction between "immigrants" and "Swedes" (Sciortino 2012)? 
If addressing racial and ethnic inequality and marginality are important values of social science research, how should one go about it in the Swedish context? How does one research the dynamics of racial and ethnic categorizations and the identities and exclusions that accompany those categorizations while remaining sensitive to context? And how does one do it in light of "treacherous bind" associated with research on race and racism - that engaging the social reality of racial categorizations and the history of racialized exclusions can itself become a form of race essentialism (Radhakrishnan 1996; Gunaratnam 2003)? We believe American racial reasoning provides a solution.

The aim of this article is to lay the groundwork for a social science seeking freedom from racism toward non-white, non-Western and/or Muslim immigrants in Sweden. We argue that importing American racial reasoning to Sweden can shed new light on the construction of racialized immigrant outsiderness, the processes of inequality that enable discrimination against immigrants, and the ideologies and interpretations that sustain the idea of Swedishness-under-threat from immigrants. It can contribute to Mulinari and Neergaard's (2017:88) aim of "putting the study of racism, a fundamental principle of social organization in modern society, at the center of social theory" in Sweden, exposing the structures and processes of inequality, and paving a path toward research that can help bring about social justice.

\section{American racial reasoning}

The idea of American racial reasoning $(A R R)^{2}$ was introduced by anthropologist Beth Epstein (2016) and, in this article, we develop ARR as a theoretically-informed way to do sociology that maintains a focus on questions of racial justice. The desire to blend moral concerns and the empirical commitments of social science is a common motivation for innovation in theory and research (see, for example, Collins 2019; Alexander, Lund \& Voyer 2020).

American racial reasoning provides a set of themes and sensitizing concepts as a structured framework for doing sociology. We ground ARR in the sociological literature on race emerging primarily from anglophone, US sociology. We then apply ARR in the Swedish context and demonstrate the analytical value of ARR when it comes to understanding social inequality and exclusion in Sweden. We argue in favor of importing American racial reasoning to Swedish social science research as a way to mainstream the consideration of race, racism, and racialized exclusions, and to center future research on addressing inequalities of power through the embrace of difference, instead of the denial of it.

American racial reasoning is largely consistent and compatible with most formulations of intersectionality, post-colonial theory, and critical race theory as these theories also tend to highlight categorization and division as key elements of racism, power, and empire (see, for example Spivak 1988; Crenshaw 1989; Radhakrishnan 1996; Collins

2 Following Epstein, the term American is used here to represent the United States. This common practice is not literally accurate, given that there are many nations that qualify as American. 
2019). Our unique contribution is the development of a structured research approach that reflects an underlying epistemology of racial difference, struggle, and emancipation that is grounded in the US framework as laid out below. This "American" flavor is channeled through the colonial episteme, sensitive to intersections of privilege and oppression, and recognizable in other attempts to take up the topics of race and racisms in other contexts (see, for example Skovdahl 1996; Winant 2001; Dixon \& Telles 2017; Sayyid 2017). Important research on race and racism is not confined to the United States, but our goal is to harness the potential of race from a US perspective in order to provide a contribution to the research landscape that can encourage further movement to racially-aware social science.

American racial reasoning, as described by Epstein (2016:168), was borne of the United States' racial history and "allows a discursive space from which to consider racial matters that are otherwise difficult to address [...]." Engaging difference and inequality through ARR links categorization processes to quests for justice like those that arise in the context of the US's ongoing failure to realize the lofty ideal of democratic equality. Looking at race and racism through the lens of ARR means seeing race as an idea (Wacquant 2005; Smedley \& Smedley 2012) - a "historically constructed principle of social classification" (Wacquant 2008:17, note 4) that supersedes any individual perspective and exists, latent, even when it is not implicitly or explicitly used. This view of race arose in the particularly American historical circumstance of the establishment of a democracy in an active slaveholding society (Wacquant 2005). According to Wacquant $(2005,2008)$ race, therefore, was framed as an exception to democracy and, in the United States, race operates as an exception that designates people who are separate, less capable, less worthy, and even less human. Even after slavery as an institution ended, the idea of race as an exception has been upheld by regimes like Jim Crow, the idea of "urban social problems," and mass incarceration and the denial of basic rights of citizenship to people who were once incarcerated.

Despite the construction of race as an exception upon which systems of repression and exclusion are built, ARR does not turn away from race and socially-constructed race categories, but instead sees possibility and potential in race and ethnic identities and categories and makes them the key to achieving racial justice. ARR engages race categories, examines their contexts and elements, uses them to expose racist social structures, and challenges the essentializations and naturalizations that sustain the idea of racial inequality. As a result, ARR offers hope for change because "racial politics carry a promise of redemption [...], a basis from which to comprehend otherwise diffuse forms of social inequality, and the illusion, at least, of a solid foundation from which to act" (Epstein 2016:169). Epstein notes that ARR could intervene in France's struggles with racialized segregation and inequality. In the following pages we show how we have applied ARR to the Swedish context. While we believe ARR could be used to explore the experiences of other minority groups in Sweden and other contexts, we maintain our focus on this division between "immigrants" and "Swedish." 


\section{Abstract concepts in the Swedish context}

In the social sciences, race and ethnicity are generally treated as overlapping concepts (for an overview of these concepts, see Winant 2000; Golash-Boza 2016). Ethnicity is more closely tied to cultural characteristics, race to biological characteristics. Race is also generally seen as a category of difference that is tied to power as racial boundaries are frequently imposed, hierarchical, exclusive, and unequal. Ethnicity is seen as more cultural, voluntary, self-defined, nonhierarchical, fluid, and not so closely linked with power differences. ${ }^{3}$ Race categories are formed through the process of racialization in which new ideological boundaries of difference are drawn around a formerly unnoticed group of people. In this way, ethnicity can be racialized when it is subsumed under a forced label and linked to appearance. Immigrants can be racialized as well, as has occurred in Sweden. Once formed, race categories are fundamental organizing principles of social life at the micro and the macro levels of society as differences in power are reinforced by continuity between structure and culture. Racism is cultural as it operates through belief in the idea that people in different racial categories possess different and unequal human traits, but racism is also an element of social structure through the operation of institutions, policies, and practices that foster or perpetuate racial hierarchies.

Voyer first became aware of her American understanding of the role of race in social science when she arrived in Sweden to conduct research on immigration and schooling. In an English-language interview with a Swedish high school headmaster, Voyer, drawing on her sociological training in the US, saw race and ethnicity as closely related concepts as described above. She posed what she assumed to be a clear and benign question about the racial and ethnic diversity of the school's students: "What are the different ethnic and immigrant populations in this school?" Since in the United States such a question was common, Voyer expected the headmaster to describe the diversity of the student body (for example nationalities, languages, race and ethnic groups represented). Instead, it was as if a cold wind blew through the room. The headmaster, who had been polite and friendly until that moment, crossed his arms over his chest and pursed his lips. "That," he said, "is a racist question." Voyer reported this interaction to her Swedish colleagues, who tended to agree with the explanation the headmaster supplied when Voyer followed up during the interview: people are individuals and to assume that they can be known or defined by group characteristics is both inaccurate and morally offensive, just as emphasizing race and ethnicity and looking for them in social life is racist. The headmaster rejected Voyer's interest in race and ethnicity as a way to shed light on social dynamics in the school. So, too, do some Swedish social scientists resist examining the social facts of race and racism in

3 It is noteworthy that no data on ethnicity is collected by Statistics Sweden, but the definition of ethnicity, as taken from the national encyclopedia, is more in line with social science definitions of race than ethnicity. The definition emphasizes shared lineage, endogamy, territory, and shared physical features as well as shared culture (Statistics Sweden 2002:19). 
Sweden, although there are also efforts to bring conversations about race and racism into greater focus (e.g. Molina 1997; Neergaard 2002; Lundström 2007; Brännström 2016; Mulinari \& Neergaard 2017; Hübinette \& Wasniowski 2018).

In other words, what could be taken for a momentary faux pas in an interview was more than just a cultural misunderstanding. Such cross-cultural challenges do not merely reflect differences in what is and is not appropriate to say, they reveal differences in racial reasoning. The headmaster's not-so-deeply buried moralizing rested on a system of belief, including the endorsement of an egalitarian individualism and color-blindness that are widely valued in Sweden (Berggren \& Trägårdh 2006; Lund \& Voyer 2019). But how, Voyer asked herself as she continued with the research, can I describe the racialized structural inequalities operating through school choice at the gymnasium level - the operation of a system which values white "ethnic Swedishness" - if I cannot talk about race (Voyer 2018)? How can I highlight the racialized devaluation at play when students use their different ethnic backgrounds and cross-cultural experiences to connect to and be seen by one another while headmasters tend to see student backgrounds as a liability and a distraction (Voyer 2016)? Voyer's use of racial and ethnic categories and the principal's refusal of them is the point: racialized power, race-based inequality, and marginality are possible even in contexts where the idea of race is discredited (Epstein 2016; Jensen, Weibel \& Vitus 2017; Sayyid 2017). And, as our work shows, in such contexts, racialized power and inequality can be especially potent.

Race is a concept with a long and complicated global history, while it is also an element of everyday life (Skovdahl 1996; Catomeris 2004; Smedley \& Smedley 2012). Here in Sweden, the contemporary movement against structural racism recently highlighted Carl von Linnés's scientific contribution to the idea of white supremacy and racial science: the idea that phenotype, including skin color, was linked to other traits like intelligence, creativity, and honesty (da Silva 2020). That the foundational insights that led to scientific racism arose in Sweden is a topic covered in many introductory sociology courses on race and ethnicity in the United States. ${ }^{4}$ The concept of race was born in Sweden, and for better and worse, ideas circulate just as people, currencies, and viruses do. Possibilities for greater social justice as well as great social harm arise as a result of the movement of concepts across time and space.

Nigerian novelist Chimamanda Adichie's description of her experiences with race in the United States illuminates the challenges and possibilities that arise as people, ideas, and concepts move across contexts. Before she arrived in the US, Adichie didn't think of herself as black, because as she puts it, "I didn't have to. I thought of myself as Igbo, which is my ethnicity" (Adiche \& Bianculli 2013). But one day as she was strolling down a street in Brooklyn, an African-American man greeted her as "sister". He was evoking familiarity and mutual recognition borne out of the presumption of shared history and social position. When Adichie heard the familiar greeting from a stranger,

4 For example, prominent race scholar Golash-Boza (2018), describes Linné's contribution in her lecture "Where does the idea of race come from?". 
her emotionally charged reaction was: "I am not your sister" (Adiche \& Bianculli 2013). Over time and on the basis of her experience in the United States, however, Adichie was drawn into the national context. Sharing the burden of being othered, of slavery, of white guilt, and more, she grew to understand American blackness. Years later, when asked if she would respond differently now, Adichie admitted she would respond with warmth to the man who had called her sister. She had not understood it at the time, but there was a bond between them (Adiche \& Bramme 2018).

Of course, Nigeria has its own categorizations as well. How "otherness" is understood and acted upon in any given context is a question for inductively performed analysis. The imperfect relationships between identities, social categories, their markers and boundaries reveal cultural processes of exclusion and inclusion. As we describe below, employing American racial reasoning means being open and analytically sensitive to local forms of racialized social organization in the interest of identifying possibilities for challenging stigmatization and building civil solidarity by supporting a more expansive understanding of Swedishness and belonging. Adichie understood her blackness in a new way as a result of her encounter with the United States. She forged new connections and attachments, but there were also moments in which she realized she was being seen as inferior. In her undergraduate studies in the US, she observed how surprised her classmates and instructor were by her superior academic performance. She "realized that the person who wrote the best essay wasn't supposed to look like me" (Adiche \& Bianculli 2013). Even if you don't believe in race categories you encounter in a new setting, you can be the subject of categorization and experience the privilege or oppression that goes along with those categories.

Like any social category, race categories "are in a constant state of production and negotiation with other forms of difference, and within specific social, historical, and interactional arenas" (Gunaratnam 2003:32). However, American racial reasoning is not only a collection of folk concepts grounded in the particular geography and history of North America (Wacquant 2005; Smedley \& Smedley 2012). ARR also sensitizes researchers to particular aspects of social life, such as the many social, political, institutional, historical and cultural webs of meaning that Adichie encountered when she arrived in the United States. Race categories are not merely context-specific classifications, they underwrite dynamics of inclusion and exclusion.

The names and contents of race categories are context-dependent, but the fact that all social categories stand in some relation to majority/minority, established/outsider, core/periphery distinctions provides crucial explanatory leverage on the social world outside of the United States (see, for example Simmel 1971[1908]; Elias \& Scotson 1994[1965]; Durkheim 1995[1912]; Alexander 2006). Race is a hopelessly fraught concept that can never be separated from its past meanings. However, race is a concept that can be used in a deconstructed form in order to uncover racism (Hall 2011). Accordingly, as we show below, American racial reasoning can be useful for Swedish social scientists. 


\section{American racial reasoning in the literature}

The extant body of work on race and ethnicity includes many theories of race relations, racial inequality, racialization and racism, and stigmatization - all offering an account of the role of race in social life (for reviews of the literature, see Winant 2000; Brubaker 2009; Golash-Boza 2016). We engage this literature with the type of theoretical pluralism advocated by Reed (2011): combining multiple and even conflicting theories on the basis of deep-seated commonalities and resonances arising from a shared engagement with the concept of race as a theorizable, important, and inescapable social fact. We argue that these underlying commonalities, which constitute American racial reasoning, arise because, more than many other nations, the United States wrestles with the ramifications of its long history of inconsistency in claiming ideals of liberty and equality while maintaining a race-stratified society (Myrdal 1944; Wacquant 2005) and relying upon the economic and industrial largess produced by a color-based caste system (Bonacich 1972). If we consider race as a concept with strong ties to colonialism and the history of slavery in the United States, it may explain why in some other national and cultural contexts there is a reluctance to adopt ARR. In Sweden, the concept of race is widely believed to be tainted by its association with eugenics, forced sterilizations, and mass killings (Hübinette, Hörnfeldt, Farahani et al. 2012). Similar stances have been observed in France and Denmark as well (Epstein 2016; Jensen, Weibel \& Vitus 2017).

Our engagement with the literature highlights the broad scope of work demonstrating aspects of American racial reasoning. Our summary of the literature is not exhaustive, but does indicate common themes that we used to build a systematic tool for looking at the topic of racism and racial inequality in the Swedish context. One way to move forward from this article would be to compare how one does research on race and racism using ARR with research using other racial reasonings developed in other contexts.

\section{Beyond race essentialism}

American racial reasoning is incompatible with essentialist understandings of race and ethnicity because ARR recognizes that race and ethnic categories change over time. Consider for example the changing race categories in the United States census. Over more than 200 years of decennial censuses, a variety of different categorization schemes have been used to classify and count the American population. Imagine in the contemporary US applying the 1890 national census categories for non-white black, mulatto (half black), quadroon (one-fourth black), and octoroon (one-eighth black) - which drew upon ideas from eugenics and race science to specify degrees of blackness considered continuous with degrees of moral, mental, and social fitness. The categories from that time were grounded in a particular social/moral order consisting of beliefs, feelings, and perspectives that shaped even the scientific "objectivity" of eugenics (Selden 1999). If past US racial logics and classifications do not apply to the present United States, it must be acknowledged that contemporary US race categories are also grounded in their own time and place. 
The work on colorism further undercuts essentialist understandings (for a review of literature, see Dixon \& Telles 2017). Research demonstrates that, in different national and historical contexts, skin tone, which is generally measured in gradations from light to dark, varies in its relationship to extant racial categories (Banton 2012; Monk 2015; Garcia \& Abascal 2016). Skin tone operates as one among many factors (including also, for example, occupation, religion, culture, language/dialect, other physical features) influencing the racial categorization of individuals (Sen \& Wasow 2014). While the relative advantage of lighter skin tones appears to be converging toward the dominance of a white/Western standard, evidence suggests that, particularly outside of the reach of Western colonialism, lighter skin-color preferences do not always hold (Jablonski 2012). Furthermore, there is very little research on the meaning of skin tone in Europe, and what little exists suggests historical and gender variations in skin tone preferences (Dixon \& Telles 2017).

\section{Racial structures}

Accepting that race is not a biological fact, the focus of American racial reasoning is on the role of race as an organizing principle of social life. US scholars of race typically claim that, despite local particularities, race is a structuring principle of social organization around the globe (Winant 2001; Smedley \& Smedley 2012; Feagin 2014; Emirbayer \& Desmond 2015). Emirbayer and Desmond (2015:5), for example, theorize a "global racial order" consisting of "organized social relations, symbolic classifications, and even collective emotions in terms of a white/non-white polarity."

American racial reasoning moves beyond essentialism, decouples race from phenotype, and connects it to social structure, social organizations and social institutions (Bhatt 2013; Bonilla-Silva 2014, Omi \& Winant 2014; Wooten \& Couloute 2017; Ray 2019). For example, in the case of redlining rules for assessing the desirability of neighborhoods for home loans in the United States, "low-risk" neighborhoods were defined as areas inhabited primarily by whites, while "high-risk" neighborhoods were inhabited primarily by people of color. These risk designations reinforced existing inequality by making it easier for white people to get mortgages with good terms, and making it more difficult for people of color to get similar terms on mortgages (Hillier 2003).

Racist social structures depend upon meaning. Ray (2019:31) argues that race becomes an element of social structure when practices for categorizing and judging on the basis of race - racial schemas - are connected to resources in ways that advantage some racial groups over others. Schemas are habits, assumptions, associations, "templates for social action" as an "unwritten rulebook explaining how to write rules." Once formed, racialized structures can reproduce or rewrite race, they can legitimate it or obscure racial inequality, but this way of theorizing race is only possible when "placing broadly shared racial schemas at the center of a structural theory of race” (Ray 2019:35). We believe American racial reasoning reveals these broadly shared schemas. 


\section{Resistance to American racial reasoning}

Resistance to the analytical value of American racial reasoning has taken many forms - from the strong stand that the idea of race is problematic because it creates racial divisions and must be abolished before there can be a world without racial hierarchies (Gilroy 2000), to more moderate claims that race-categorical thinking is too rigid (Parker \& Song 2001), to the argument that the use of folk categories of race by social analysts essentializes and homogenizes human experience (Loveman 1999), to the claim that the concept of race ultimately privileges the white/nonwhite polarity of the colonial episteme (Spivak 1988). Theoretical concerns aside, still others challenge the empirical accuracy of race concepts. For example, Wimmer (2015:2197) argues that neither the historical record nor contemporary data support "Atlanto-centric" arguments for the historical and operational distinctiveness of racial discrimination as opposed to, for example, discrimination on the basis of religion, or region. In light of the challenges associated with the concept of race, Brubaker, Loveman and Stamatov (2004) call for a cognitive turn in recognizing race, ethnicity and nationalism as analytically undifferentiated categories used to see the world, act in it, and make sense of it.

We argue that American racial reasoning requires a cultural instead of a cognitive turn. Brubaker, Feischmidt, Fox et al. (2006:208, note 3) assert that race and ethnicity as cognition are "done" in the moment and within interaction. They acknowledge that ethnicity is cultural: "there are of course important aspects of ethnicity that are continuous" including "embodied schemas of interpretation [...] discursive forms, repertoires of contention, and objectified symbols such as flags, maps, and monuments," but they dismiss the significance of shared meaning and claim that everyday ethnicity is "fundamentally intermittent and episodic." Such an interactional approach to race and ethnicity emphasizes fleeting moments and immediate circumstances while neglecting shared categories, meanings, and practices and dismissing the significance of knowledge and perspectives that individuals accumulate through their experiences in the lived, everyday world (Smith 1987). After all, shared meaning, not modes of interaction, makes it possible for people to interpret and reinterpret their social experiences as "racial," "ethnic", or "nationalistic" instead of just awkward, conflictual, or routine (for an example of the tension between racial meaning and problems of "doing" race, see Garfinkel 1941).

\section{Elements of American racial reasoning}

Accepting that specific race categories are folk ideas that vary across social and historical contexts does not necessitate that American racial reasoning cannot be used productively across contexts to uncover the shared schemas that connect race categories and racist social structures. Drawing upon the literature, we extend Epstein's concept of racial reasoning from a perspective to a research paradigm focusing on several key elements of race in social life: 1) Symbolic construction of otherness: race as a social, cultural, and/or symbolic construction without a basis in biological or genetic determination; 2) Legitimating ideology: an ideology of difference that justifies social exclusion, subjugation, exploitation or extermination of racialized others; 3) Perceptibility: racial categories are generally ex- 
perienced as recognizable through associations with phenotype, style of dress, manner of speaking, neighborhood, or some other observable characteristic; 4) Institutionalized practices: racial categories may be assigned and enforced by institutionalized practices that segregate and subordinate racially designated groups (for example, through legal systems which determine criteria for racial categorization and legislate racial and ethnic relations); 5) Identity: one's race may also be asserted as a collective social and political identity (see, Table 1. For different examples of race concepts that contain many of these components see Essed 1991; Bonilla-Silva 1999; Wacquant 2005; Smedley \& Smedley 2012; Feagin 2013; Omi \& Winant 2014; Emirbayer \& Desmond 2015).

Table 1. Elements of American racial reasoning

\begin{tabular}{|l|l|}
\hline 1. Symbolic construction of otherness & What categories designate "otherness?" \\
\hline 2. Legitimating ideology & What ideas legitimate exclusions? \\
\hline 3. Perceptibility & $\begin{array}{l}\text { What characteristics make category membership } \\
\text { recognizable? }\end{array}$ \\
\hline 4. Institutionalization & $\begin{array}{l}\text { How are symbolic categories and exclusions institu- } \\
\text { tionalized in structure and action? }\end{array}$ \\
\hline 5. Identity & $\begin{array}{l}\text { How are categories adopted and expressed as political } \\
\text { and social identities? }\end{array}$ \\
\hline
\end{tabular}

In seeking to understand American racial reasoning and apply it to research in Sweden, the question is not whether or not Sweden has "race," nor what the boundaries between race, ethnicity, and nationalism are, but instead, how racialization occurs and racialized categories are made meaningful in relationship to these elements. We demonstrate this approach below.

\section{Importing American racial reasoning to Sweden}

American racial reasoning is rooted in meaning, not biological determinism, interactions, materialism or social structure. Applying ARR to the Swedish context means being open to the ways in which the processes of social inequality operate in and through categories of racial and ethnic difference, while simultaneously seeing the path to greater equality in the embrace of those categories of racial and ethnic difference as welcomed variations on the theme of Swedishness. ${ }^{5}$ The five elements of ARR will point out the symbolic landscape of race, and using them assists in developing an understanding of how social life unfolds in racially classified, categorized and symbolic social spaces in Sweden.

5 Alexander (2006:450-458) refers to such an embrace as difference as the multicultural mode of incorporation. 
After providing a brief overview of the Swedish context, we will briefly show applications of American racial reasoning to our research in immigration and education. As stated previously, immigrant is a racialized category in Sweden. In recent years, immigration has increased in many countries that are not typically seen as diverse, immigrant-receiving nation-states. Sweden is one such country - a place that was typically, if erroneously, considered a homogenous nation experienced a rapid increase in its foreign-born population (Swedish Migration Agency 2020). In 2017, 18.5\% of the population was born outside of Sweden (Statistics Sweden 2018c). There is also a substantial immigrant second generation. In 2016, 13\% of children under age 21 had two foreign-born parents, and an additional $12 \%$ of children had one foreign-born parent (Statistics Sweden 2018b). Sweden's immigrants come from many nations. In order of population size, the top ten countries represented in Sweden's new immigrant population in 2017 were Syria, Afghanistan, Iraq, India, Poland, Iran, Eritrea, Somalia, China and Finland (Statistics Sweden 2018a).

Newcomers to Sweden arrive in what is generally considered one of the most wellfunctioning of the modern democratic societies, a country recognized as exemplary in its pursuit of class and gender equality and a high quality of life (Esping-Andersen $\&$ Wagner 2012). This view is challenged by scholars who argue that most measures of social welfare and quality of life do not take adequate account of inequalities in power and intersecting vectors of privilege and oppression (Pringle 2010), the inadequacy of historically-rooted conceptions of monolithic and homogeneous social solidarity in the face of large-scale immigration (Lister 2009), and the rise of racism in Sweden beginning in the 1990s (Pred 2000). In recent years, and coinciding with the dramatic increases in immigration, increasing residential and school segregation and the rise of a segmented labor market indicates that social inequality and stratification are testing the social welfare state (Trygged \& Righard 2019). Anti-immigrant right wing politics and a mainstream desire to limit and control migration are also on the rise (Rydgren $\&$ van der Meiden 2019).

\section{Symbolic construction of otherness: Social categories}

While typical American race categories may not be used in Sweden and some social scientists and laypeople resist the recognition of race and ethnic groups, there are categories that designate "us" and "others" in everyday parlance. In our research applying ARR in Sweden, we uncovered the active symbolic classifications used in everyday life. We collected our fieldnotes and interview transcripts and reread them in order to create a list of common classifications and the meaning that those classifications had to the people who used them. We observed that symbolic classifications often match some other social classifications such as legal designations. For example, in the United States, citizen is a political classification that provides access to the vote and financial aid for higher education, but "citizen" is also a symbolic category designating other implicit and explicit social meanings, such as evoking the idea of commitment to the nation, and a feeling of privileged mutuality with other citizens (Bloemraad 2017, for a similar consideration of citizenship in the Swedish context, see Dahlstedt, Fejes \& 
Olson 2017). Just as one cannot assume that the folk category of immigrant refers to people who are actually immigrants, a one-to-one relationship between the boundaries of symbolic category (for example, through those recognized as "citizens") and the boundaries of the category in some other sphere of life (for example, legal citizenship) cannot be assumed. In the Swedish context for example, people who have "immigrant" backgrounds but are Swedish citizens are frequently referred to as "new Swedes" instead of just "Swedes," and, as Barker (2017) notes, symbolic categories of the Swedish people (folk) have ramifications for policy, for example in the construction of border policies and citizenship criteria.

In our data, we have observed common use and shared understanding of a system of racial and ethnic categorizations in Sweden. The system included the categorizations of immigrant (invandrare), refugee (flykting), Swedish (svensk) and derogatory terms for non-white immigrants ("blatte") and ethnic swedes ("svenne") as well as different religious and nationality groups (see Table 2 for an abbreviated list of categories). In other work, we have described what these categories mean in everyday life and used the categories to discuss the possibilities for immigrant integration in the Swedish context (see Lund \& Voyer 2019).

Table 2. Swedish categories

\begin{tabular}{ll} 
Common categories & Descriptions \\
\hline Immigrant & $\begin{array}{l}\text { Negative characterization that evokes the ideas of chaos and } \\
\text { criminality. }\end{array}$ \\
\hline Refugee & $\begin{array}{l}\text { A questioned belonging, in a symbolic and juridical sense, that } \\
\text { evokes pity, the assumption of deficiency, backwardness, and } \\
\text { increasingly deceit. }\end{array}$ \\
\hline Muslims & $\begin{array}{l}\text { Negative stereotype seeing problematic groupness and unen- } \\
\text { lightened behaviors around sex and gender. }\end{array}$ \\
\hline "Blatte" & $\begin{array}{l}\text { A derogatory term for people with a non-Swedish ethnic back- } \\
\text { ground, but familiarity with Sweden. A hybrid identity that } \\
\text { incorporates both positive and negative poles of belonging. }\end{array}$ \\
\hline "Svenne" & $\begin{array}{l}\text { A derogatory term for ethnic Swedes or immigrants who are } \\
\text { judged to be assimilating to Swedishness. Evokes deceitfulness, } \\
\text { falseness, and a lack of individuality. }\end{array}$ \\
\hline Swedish & $\begin{array}{l}\text { A positive term when connected to shared conceptions of appro- } \\
\text { priate behavior (not being lazy, contributing to society). An exclusive } \\
\text { term when designating white Swedish ethnicity. }\end{array}$ \\
\hline
\end{tabular}

6 We thank an anonymous reviewer for highlighting this relevant fact. 


\section{Legitimating ideology: State individualism}

Along with these categories, American racial reasoning highlights ideologies that are used to make sense of exclusion and inequality on the basis of categorization. One such ideology is Sweden's strong emphasis on individualism and corresponding distrust of subgroup attachments. The Swedish state promotes individual independence through the elimination of obstacles to individual self-realization and the adoption of an individual-oriented approach to its citizenry (Berggren $\&$ Trägårdh 2006). For example, married and cohabiting adults are taxed and receive their social benefits as individuals instead of as a family unit, which reinforces the notion that a family consists of independent individuals. While a potential source of individual liberty, it should be noted that this "state individualism" is a cultural construction incorporating elements that are consistent with the practices and perspectives of the ethnic majority. Meanwhile, state individualism can prove problematic for minorities because it may clash with the notion of active social subgroups. Most social subgroups are viewed with suspicion on the basis of the assumption that group members' individuality is subordinated to and thwarted by group mandates and practices. According to Berggren and Trägårdh (2006), independence and selfrealization among independent individuals constitute the social contract of Swedish society (see also Lund 2017a). An ideology of individualism legitimizes exclusions of those who appear committed to non-native racial, ethnic, and religious subgroup identities and attachments that are believed to threaten the individuality of group members. Such shared identities and "groupness" are generally seen as inconsistent with the ideology of Swedish state individualism.

The application of American racial reasoning incorporates examination of the underlying mainstream ideologies that uphold group boundaries and justify unequal outcomes. Thus, ARR shifts the perspective from what are assumed to be problematic aspects of minority group culture (for example, the argument that immigrants choose segregation) to barriers erected by often unquestioned and unchallenged cultural assumptions of the Swedish mainstream.

\section{Perceptibility}

The symbolic construction of otherness and a legitimating ideology are crucial elements of American racial reasoning and the processes of racialization and exclusion that a racial analysis seeks to expose. However, in order to have influence in the social world, abstract categories and values must become perceptible through linkages to observable behaviors and characteristics. In Sweden, links between having an "immigrant background" and "failed individualism" are read through behavioral characteristics such as the decision to wear a veil or being more gregarious in school settings. These links between perceptibility factors, categorizations, and ideology are often mistaken for natural, emergent, and singularly correct truths. For example, the school headmaster in the quotation below compares two schools she has worked in, one school with immigrant students and another with non-immigrant students: 
At the other school [...] a higher percentage of those students come from the eastern part of Malmö [primarily Muslim, immigrant neighborhoods]. It is a rougher environment. If you get inside here [ethnic Swedish school], there is not so much noise. It is rather quiet and calm. The situation at the other school is not the same. Some of the other students are very noisy. They are totally nuts. They are not mentally well. Some of them are traumatized. We thought from the beginning that several of them are traumatized by war. But when we asked them if there had been war in their home countries and very, very few said yes. Most of them were born here.

The headmaster links the unspoken categorization of immigrant outsiders with behavioral markers she interprets as evidence of their outsiderness. In our research (Lund \& Voyer 2019) we identified the visibility markers of different symbolic categories (see Table 3). 
Table 3. Perceptibility of selected common categories

\begin{tabular}{ll}
\hline Categories & Visibility factors and stereotypes \\
\hline Immigrant & Living in neighborhoods with fewer ethnic Swedes. \\
& Accented or imperfect Swedish. \\
& Possibly darker hair color and complexion. \\
& Non-Swedish name. \\
& Not from a country in Western Europe or the global north. \\
\hline Refugee & Do not speak Swedish. \\
& Lack of employment. \\
& High use of social services. \\
& Darker hair color and complexion. \\
& Not dressing in modern Swedish or Western clothing. \\
\hline Muslim & Separate organizations (for example, setting up own schools). \\
& Married women staying out of the workforce. \\
& Praying and wearing religious markers (for example, the veil) in \\
& public. \\
& Darker hair color and complexion. \\
& Non-Swedish or Non-Western name. \\
& Young. \\
& Longer residence or lifelong residence in Sweden. \\
& "Urban" style and culture. \\
& Living in or socializing in an immigrant neighborhood. \\
& Speaking dialect associated with neighborhood. \\
& Attending vocational programs or schools with many immigrants. \\
\hline Blatte" & Being an outspoken proponent of a correct way to be Swedish. \\
& Claiming Swedishness is under threat. \\
& Right wing or nationalist views and party affiliation. \\
& Lighter hair and complexion. \\
& Speaking unaccented, standard Swedish. \\
& School achievement. \\
& Joining mainstream Swedish activities and organizations. \\
& Not being engaged in the social life of immigrant neighborhoods. \\
& Participating in the Swedish welfare state (working, school, paying \\
& taxes, using welfare benefits as intended). \\
& Speaking good Swedish. \\
& Avoiding subgroup expressions and attachments. \\
& Generally white or mixed race with generally lighter colored hair. \\
\hline "Svenne" & \\
\hline & \\
&
\end{tabular}




\section{Institutionalized practices}

Symbolic categories and exclusions can become institutionalized in structure and action. Explicit decisions on the basis of categorical membership can lead to the institutionalization of racism. For example, in the case of denying a non-citizen access to social benefits or denying long term residents' access to citizenship because they are not proficient in Swedish. But institutionalization can also occur indirectly through links to perceptibility factors. American racial reasoning assists with the identification of such less direct linkages and the institutional discrimination resulting from them.

For example, in our research on the relationship between school choice policies and school segregation in Sweden, we observed how headmasters' organizational work inscribes racial preferences for Swedishness on the structure of schooling (Voyer 2016, 2018). In light of predominant beliefs that "immigrant" schools are bad schools and "Swedish" schools are good ones, principals engage in different practices to develop schools aligned with a presumed preference for Swedishness among school-choosers. The same headmasters who deny the significance of race and ethnicity in their school institutionalize racial exclusion by emphasizing Swedish perceptibility factors in their advertising, seeking to meet the preferences of ethnic Swedish students when selecting programs of study, and hiring teachers who only speak with unaccented Swedish.

\section{Identity}

American racial reasoning sheds light on the complex relationships between symbolic categories and selves. Symbolic categories may be adopted and expressed as political and social identities, but there is a distinction between symbolic categories and identities. One may have an identity, that is a sense of self and group belonging, that is exceedingly salient to one's everyday life but, yet, carries no weight as a social symbolic category determining how one is seen by others or situated in the social world. Alternatively, one may be assigned a categorization that is either antagonistic or orthogonal to one's identity. Instead of being grounded in some objective reality of group differences, symbolic categories are analytically distinct from identities.

In their social lives, all people reside in multiple socially symbolic categories and also hold multiple identities derived in part from their history and experiences in a uniquely classified social world. These multiple categories and identities are more than additive in their impact on social life and the dynamic intersections of nationality, ethnicity, religiosity, culture, and race as lived experience are not easily clarified (Collins 1986; Crenshaw 1989). Analyzing the ways in which people's own racialized identifications help them reflect on and rewrite the limitations of context is crucial.

Applying American racial reasoning in Sweden sheds light on the complexities of identity and belonging among immigrant-background youth. One such youth is Fedra, who immigrated to Sweden from Turkey with her family when she was eight years old. Fedra, a high school student and practicing Muslim who wears a hijab, is performing well in school and firmly on track to reach her goal of becoming a scientist. She feels that she both is and is not Swedish, and she is Turkish, too. 
As long as you feel Swedish, you are perhaps Swedish. But one should not think it's embarrassing to be non-Swedish. I am from Turkey. I am Turkish, but at the same time, I am also Swedish somehow. We cannot deny it. I am a Swedish citizen [...] But when it comes to ethnic groups, I do not think you can be Swedish when one is Turkish. But one can simultaneously be Swedish, but I do not think we should forget our origins. But that does not mean you should be treated badly by the Swedes.

Given the racialized conceptions of Swedishness that conflict with a more civil- and citizenship-based sense of Swedishness that Fedra seeks to adopt, she experiences her identities, categorizations, and belongings as overlapping, intersecting, and, conflicting and contradictory. Forming identities in light of experiences living within, betwixt, and between symbolic categories presents unique challenges as well as novel sources of agency, creativity, and freedom of thought (Lund 2017b).

American racial reasoning helps uncover multiple processes of social inequality operating on the basis of racialized power. On the one hand, categories of difference may be imposed on youth like Fedra, whose Swedishness may not be accepted by individuals who believe her name, religion, and/or complexion disqualify her from inclusion, and by institutional structures built on the basis of that belief. On the other hand, categories of difference can be denied by the imposition of a colorblindness that limits Fedra's opportunity to embrace and express her Turkish identity, which she sees as part of who she is. What are the possibilities for inclusion and equality under such circumstances? ARR engages categories of racial and ethnic difference and explores their social meanings, while simultaneously seeing the path to greater equality in the creation of a more expansive definition of Swedishness that embraces those differences.

\section{A deconstructed view of racial otherness}

American racial reasoning calls for a focus on contextual symbolic categories, ideologies, visibility factors, institutionalization, and identities. Importing ARR to Sweden enables research on the dynamics of racial categorizations and the identities and exclusions that accompany those categorizations while remaining sensitive to context. ARR calls for a deconstructed view, avoiding race essentialism by seeing racial and ethnic categories as symbolic, but impactful, elements of the social world.

When Chimamanda Adichie moved from one national context to another, she acquired a perspective and vocabulary that gave voice to her experiences with prejudice and discrimination, and connected her to others with similar experiences. Similarly, when moved from the United States to Sweden, American racial reasoning opens up new terrain for resistance to racism and racialized exclusion. Okamoto's (2014) study of the emergence of the pan-ethnic solidarity among Asian Americans is a case in point. Asian American was first an overarching official (as opposed to symbolic) category spanning many phenotypes, religions, and ethnic and national origin groups (in some cases groups with a long history of mutual animosity). While the category Asian 
American may have made sense to a white majority who cared little to understand the differences masked by the label, it was imposed upon Asian Americans and, therefore, it was not a foregone conclusion that pan-ethnic Asian American political mobilization would emerge. The idea of Asian similarity and the view emerging in the late 1960s that racial and ethnic identities could be grounds for shared political interests and action shaped both intentions and modes of action by making pan-ethnic organizing possible as a legitimate social undertaking and feasible as a mode of political action. Many individual political leaders stuck to intra-ethnic organization building, but others adopted the novel enterprise of building pan-ethnic Asian organizations. Likewise, in Sweden, the creation of the category of immigrant has resulted in the rise of a shared consciousness and an identity based, not upon biological or cultural ties, but on the shared experience of being marginalized in Sweden (Bredström 2003).

How racialized "otherness" is understood and acted upon in any given context is a crucial question for social scientists. We believe that using American racial reasoning can contribute to building the knowledge necessary for a more equal and just society. Denying the significance of race in social science could be referred to as colorblindness - the outright denial of symbolic categories and their significance in social life, primarily by those who are in the racial majority position (Bonilla-Silva 2014). According to Bonilla-Silva, colorblind racism is the most pernicious and destructive form of racism (ibid.). The view that racism and ethnocentrism exist as a result of the study of racial and ethnic categorizations is not logically or empirically defensible. Social scientists' refusal to acknowledge and interrogate symbolic categorizations and their corresponding assumptions does not protect people from racism, it merely limits the ability to confront discrimination and inequality. Acknowledging, naming, and taking account of racial and ethnic divisions can expose processes of social distinction and ranking. Engaging extant racial and ethnic categories reveals their perceptibility factors and ideologies, undercutting problematic conclusions and ill-advised policy choices based on the problematic assumption that inequalities result from imagined group characteristics (for example, the idea that a group has a "culture of poverty" or "ethnic disadvantage"). Thus, through analyzing the symbolic construction of otherness/social categories, legitimating ideology, perceptibility, institutionalized practices and identity complex and racialized inequalities be investigated. Not least, importing American racial reasoning can help reveal the power and privilege of the white Swedish mainstream. 


\section{Acknowledgements}

The authors would like to thank anonymous reviewers and Cultural Sociology at Stockholm University for their comments and suggestions. Research was conducted through the following funded projects: Children and youth's living conditions (20182023), financed by Gålöstiftelsen; An educational dilemma: School achievement and multicultural incorporation (2010-2014), financed by the Swedish Research Council (project id 2009-06152); and Opportunity structures for inclusion and school success of newly arrived youth (2017-2020), financed by the Swedish Research Council (project id 2016-04231).

\section{References}

Adiche, C. \& D. Bianculli (2013) “'Americanah' author explains 'learning' to be Black in the U.S." Transcript of interview on Fresh Air, National Public Radio, 27 June 2013. https://www.npr.org/transcripts/195598496 (Accessed 3 December 2020).

Adiche, C. \& A. Bramme (2018) "Chimamanda Ngozi Adichie i samtal med Amie Bramme Sey", Public lecture at Kulturhuset Stadsteatern, Stockholm, 26 November 2018. https://youtu.be/fE_v6fmz1Xk (Accessed 3 December 2020).

Alexander, J.C., A. Lund \& A. Voyer (2020) "Hope and a horizon of solidarity An interview with Jeffrey C. Alexander: Interviewed by Anna Lund and Andrea Voyer", Sociologisk Forskning 57 (2):189-205. https://doi.org/10.37062/sf.57.21974 Alexander, J.C. (2006) The civil sphere. New York: Oxford University Press.

Banton, M. (2012) "The color line and the color scale in the twentieth century", Ethnic and Racial Studies 35 (7):1109-1131. https://doi.org/10.1080/01419870.20 11.605902

Barker, V. (2017) Nordic nationalism and penal order: Walling the welfare state. London: Routledge. https://doi.org/10.4324/9781315269795

Berggren, H. \& L. Trägårdh (2006) Är svensken människa?: Gemenskap och oberoende $i$ det moderna Sverige. Stockholm: Norstedts.

Bhatt, W. (2013) "The little brown woman: Gender discrimination in American medicine", Gender \& Society 27 (5):659-680. https://doi.org/10.1177/0891243213491140

Bloemraad, I. (2017) "Does citizenship matter?”, 524-550 in A. Shachar, R. Bauböck, I. Bloemraad \& M. Vink (Eds.) The Oxford handbook of citizenship. Oxford: Oxford University Press. https://doi.org/10.1093/oxfordhb/9780198805854.013.23

Bonacich, E. (1972) "A theory of ethnic antagonism: The split labor market", American Sociological Review 37 (5):547-559. https://doi.org/10.2307/2093450

Bonilla-Silva, E. (1999) "The essential social fact of race", American Sociological Review 64 (6):899-906. https://doi.org/10.2307/2657410

Bonilla-Silva, E. (2014) Racism without racists: Color-blind racism and the persistence of racial inequality in the United States. Lanham: Rowman \& Littlefield.

Bredström, A. (2003) "Gendered racism and the production of cultural difference: Media representations and identity work among 'immigrant youth' in contem- 
porary Sweden", NORA: Nordic Journal of Women's Studies 11(2):78-88. https:// doi.org/10.1080/08038740310002932

Brubaker, R. (2009) "Ethnicity, race, and nationalism", Annual Review of Sociology 35:21-42. https://doi.org/10.1146/annurev-soc-070308-115916

Brubaker, R., M. Feischmidt, J. Fox \& L. Grancea (2006) Nationalist politics and everyday ethnicity in a Transylvanian town. Princeton: Princeton University Press. https://doi.org/10.1515/9780691187792

Brubaker, R., M. Loveman \& P. Stamatov (2004) "Ethnicity as cognition", Theory and Society 33 (1):31-64. https://doi.org/10.1023/b:ryso.0000021405.18890.63

Brännström, L. (2016) “Ras' i efterkrigstidens Sverige: Ett bidrag till en mothistoria”, 27-55 in P. Lorenzoni \& U. Manns (Eds.) Historiens hemvist: II. Etik, politik och historikerns ansvar. Gothenburg: Makadam förlag.

Bursell, M. (2012) "Name change and destigmatization among Middle Eastern immigrants in Sweden", Ethnic and Racial Studies 35 (3):471-487. https://doi.org/10. 1080/01419870.2011.589522

Catomeris, C. (2004) Det ohyggliga arvet: Sverige och främlingen genom tiderna. Stockholm: Ordfront Förlag.

Collins, P. (2019) Intersectionality as critical social theory. Durham: Duke University Press.

Collins, P. (1986) "Learning from the outsider within: The sociological significance of Black feminist thought", Social Problems 33 (6):14-32. https://doi. org $/ 10.2307 / 800672$

Crenshaw, K. (1989) "Demarginalizing the intersection of race and sex: A Black feminist critique of antidiscrimination doctrine, feminist theory and antiracist politics", University of Chicago Legal Forum 1989 (1):139-167.

da Silva, T. (2020) "Statyprotesterna når Sverige: Namnlista mot Linné", SVT Nyheter Kultur, 15 June 2020. https://www.svt.se/kultur/carl-von-linne (Accessed 30 June 2020).

Dahlstedt, M., A. Fejes, M. Olson, L. Rahm \& F. Sandberg (2017) "Medborgarskapandets paradoxer", Sociologisk Forskning 54 (1-2):31-50.

de los Reyes, P., I. Molina \& D. Mulinari. (Eds.) (2002) Maktens (o)lika förklädnader: Kön, klass \& etnicitet i det postkoloniala Sverige: En festskrift till Wuokko Knocke. Stockholm: Atlas.

Dixon, A.R. \& E.E. Telles (2017) "Skin color and colorism: Global research, concepts, and measurement", Annual Review of Sociology 43 (1):405-424. https://doi. org/10.1146/annurev-soc-060116-053315

Durkheim, É. (1995[1912]) The elementary forms of religious life. New York: Free Press. Elias, N. \& J.L. Scotson (1994[1965]) The established and the outsiders: A sociological enquiry into community problems. Second edition. London: SAGE. https://dx.doi. org/10.4135/9781446222126

Emirbayer, M. \& Desmond, M. (2015) The racial order. Chicago: The University of Chicago Press.

Epstein, B.S. (2016) "Redemptive politics: Racial reasoning in contemporary 
France”, Patterns of Prejudice 50 (2):168-187. https://doi.org/10.1080/003132 2X.2016.1164434

Esping-Andersen, G. \& S. Wagner (2012) "Asymmetries in the opportunity structure: Intergenerational mobility trends in Europe", Research in Social Stratification and Mobility 30 (4):473-487. https://doi.org/10.1016/j.rssm.2012.06.001

Essed, P. (1991) Understanding everyday racism: An interdisciplinary theory. Thousand Oaks: SAGE.

Feagin, J. (2013) Systemic racism: A theory of oppression. New York: Routledge. https:// doi.org/10.4324/9781315880938

Feagin, J. (2014) Racist America: Roots, current realities, and future reparations. New York: Routledge. https://doi.org/10.4324/9780203762370

Garcia, D. \& M. Abascal (2016) "Colored perceptions: Racially distinctive names and assessments of skin color", American Behavioral Scientist 60 (4):420-441. https:// doi.org/10.1177/0002764215613395

Garfinkel, H. (1941) “Color trouble”, 97-119 in E.J. O’Brien (Ed.) The best short stories 1941. Boston: Houghton Mifflin.

Gilroy, P. (2000) Against race: Imagining political culture beyond the color line. Harvard University Press.

Golash-Boza, T. (2016) "A critical and comprehensive sociological theory of race and racism", Sociology of Race and Ethnicity 2 (2):129-141. https://doi. org/10.1177/2332649216632242

Golash-Boza, T. (2018) “Where does the idea of race come from?”, https://vimeo. com/285608477 (Accessed 30 June 2020).

Gunaratnam, Y. (2003) Researching race and ethnicity: Methods, knowledge and power. London: SAGE. https://dx.doi.org/10.4135/9780857024626

Hall, S. (2011) "Introduction: Who needs "identity"?", 1-17 in S. Hall \& P. $\mathrm{du}$ Gay (Eds.) Questions of cultural identity. London: SAGE. https://dx.doi. org/10.4135/9781446221907.n1

Hillier, A.E. (2003) "Redlining and the home owners' loan corporation", Journal of Urban History 29 (4):394-420. https://doi.org/10.1177/0096144203029004002

Hübinette, T. (Ed.) (2017) Ras och vithet: Svenska rasrelationer i gair och $i$ dag. Lund: Studentlitteratur.

Hübinette, T., H. Hörnfeldt, F. Farahani \& R. León Rosales (2012) Om ras och vithet $i$ det samtida Sverige. Tumba: Mångkulturellt centrum.

Hübinette, T. \& C. Lundström (2014) "Three phases of hegemonic whiteness: Understanding racial temporalities in Sweden”, Social Identities 20 (6):423-437. https:// doi.org/10.1080/13504630.2015.1004827

Hübinette, T. \& C. Lundström (2020) Vit melankoli: En analys av en nation $i$ kris. Gothenburg: Makadam.

Hübinette, T. \& A. Wasniowski (Eds.) (2018) Studier om rasism: Tvärvetenskapliga perspektiv på ras, vithet och diskriminering. Malmö: Arx förlag.

Jablonski, N.G. (2012) Living color: The biological and social meaning of skin color. University of California Press. https://doi.org/10.1525/9780520953772 
Jensen, T.G., K. Weibel \& K. Vitus (2017) “'There is no racism here': Public discourses on racism, immigrants and integration in Denmark", Patterns of Prejudice 51 (1):51-68. https://doi.org/10.1080/0031322X.2016.1270844

Khayati, K. (2017) "Stigmatisering och rasism i det svenska migrationssamtalet och det diasporiska motståndet”, Sociologisk Forskning 54 (1):11-30.

Knocke, W. (1986) Invandrade kvinnor i lönearbete och fack: En studie om kvinnor frän fyra länder inom Kommunal-och Fabriksarbetareförbundets avtalsområde. Stockholm: Arbetslivscentrum.

Lister, R. (2009) "A Nordic nirvana? Gender, citizenship, and social justice in the Nordic welfare states", Social Politics: International Studies in Gender, State \& Society 16 (2):242-278. https://doi.org/10.1093/sp/jxp007

Loveman, M. (1999) “Is 'race' essential?”, American Sociological Review 64 (6):891-898. https://doi.org/10.2307/2657409

Lund, A. (2017a) "At the threshold of retirement: From all-absorbing relations to selfactualization", Journal of Women \& Aging 29 (4):306-320. https://doi.org/10.1080 /08952841.2016.1187537

Lund, A. (2017b) "From pregnancy out of place to pregnancy in place: Across, within and between landscapes of meaning", Ethnography 18 (1):76-87. https://doi. org/10.1177/1466138115592419

Lund, A. \& A. Voyer (2019) “'They're immigrants who are kind of Swedish': Universalism, primordialism, and modes of incorporation in the Swedish civil sphere", 177-202 in J.C. Alexander, A. Lund \& A. Voyer (Eds.) The Nordic civil sphere. Cambridge: Polity Press.

Lundström, C. (2007) Svenska latinas: Ras, klass och kön i svenskhetens geografi. Gothenburg: Makadam.

Molina, I. (1997) Stadens rasifiering: Etnisk boendesegregation i folkhemmet. Uppsala: Uppsala University.

Monk, E.P. (2015) "The cost of color: Skin color, discrimination, and health among African-Americans”, American Journal of Sociology 121 (2):396-444. https://doi. org/10.1086/682162

Mulinari, D., \& A. Neergaard (2017) "Theorising racism: Exploring the Swedish racial regime”, Nordic Journal of Migration Research 7 (2):88-96. https://doi.org/10.1515/ njmr-2017-0016

Myrdal, G. (1944) An American dilemma, volume 2: The Negro problem and modern democracy. New York: Harper \& Brothers.

Neergaard, A (2002) "Arbetsmarknadens mönster: Om rasifierad segmentering", 116-134 in M. Dahlstedt \& I. Lindberg (Eds.) Det slutna folkhemmet: Om etniska klyftor och blågul självbild. Stockholm: Agora.

Okamoto, D.G. (2014) Redefining race: Asian American panethnicity and shifting ethnic boundaries. New York: Russell Sage Foundation.

Omi, M. \& H. Winant (2014) Racial formation in the United States. New York: Routledge. https://doi.org/10.4324/9780203076804

Parker, D. \& M. Song (Eds.) (2001) Rethinking “mixed race”. London: Pluto Press. 
Pikkarainen, H. \& B. Brodin (2008) Discrimination of the Sami: The rights of the Sami from a discrimination perspective. Stockholm: Ombudsmannen mot etnisk diskriminering.

Pred, A. (2000) Even in Sweden: Racisms, racialized spaces, and the popular geographical imagination. Berkeley: University of California Press. https://doi. org/10.1525/9780520925281

Pringle, K. (2010) "Comparative studies of well-being in terms of gender, ethnicity, and the concept of 'bodily citizenship': Turning Esping-Andersen on his head?", 137-156 in E.H. Oleksy, J. Hearn \& D. Golańska (Eds.) The Limits of gendered citizenship: Contexts and complexities. New York: Routledge. https://doi. org/10.4324/9780203831533

Radhakrishnan, R. (1996) Diasporic mediations: Between home and location. Minneapolis: University of Minnesota Press.

Ray, V. (2019) "A theory of racialized organizations", American Sociological Review 84 (1):26-53. https://doi.org/10.1177/0003122418822335

Reed, I.A. (2011). Interpretation and social knowledge: On the use of theory in the human sciences. Chicago: The University of Chicago Press.

Rydgren, J. \& S. van der Meiden (2019) "The radical right and the end of Swedish exceptionalism”, European Political Science 18 (3):1-17. https://doi.org/10.1057/ s41304-018-0159-6

Sayyid, S. (2017) "Post-racial paradoxes: Rethinking European racism and anti-racism", Patterns of Prejudice 51 (1):9-25. https://doi.org/10.1080/0031322X.2016.1270827

Schierup, C.-U. \& S. Paulson (Eds.) (1994) Arbetets etniska delning: Studier frän en svensk bilfabrik. Stockholm: Carlsson.

Sciortino, G. (2012) "Ethnicity, race, nationhood, foreignness, and many other things: Prolegomena to a cultural sociology of difference-based interactions", 365-389 in J.C. Alexander, R.N. Jacobs \& P. Smith (Eds.) The Oxford handbook of cultural sociology. New York: Oxford University Press. https://doi.org/10.1093/ oxfordhb/9780195377767.013.14

Selden, S. (1999) Inheriting shame: The story of eugenics and racism in America. New York: Teachers College Press.

Sen, M. \& O. Wasow (2014) "Race as a bundle of sticks: Designs that estimate effects of seemingly immutable characteristics", Annual Review of Political Science 19:499-522. https://doi.org/10.1146/annurev-polisci-032015-010015

Simmel, G. (1971[1908]) "The stranger", 143-149 in D. Levine (Ed.) Georg Simmel on individuality and social forms: Selected writings. Chicago: University of Chicago Press.

Skovdahl, B. (1996) Skeletten i garderoben: Om rasismens idéhistoriska rötter. Tumba: Mångkulturellt centrum.

Smedley, A. \& B.D. Smedley (2012) Race in North America: Origin and evolution of a worldview. Boulder: Westview Press. https://doi.org/10.4324/9780429494789

Smith, D. (1987) The everyday world as problematic: A feminist sociology. Boston: Northeastern University Press. 
Spivak, G.C. (1988) “Can the subaltern speak?”, 271-313 in C. Nelson \& L. Grossberg (Eds.) Marxism and the interpretation of cultures. Urbana: University of Illinois Press. Statistics Sweden (2002) "Personer med utländsk bakgrund: Riktlinjer för redovisning i statistiken”, https://www.scb.se/contentassets/60768c27d88c434a8036d1fdb595 bf65/mis-2002-3.pdf (Accessed 30 June 2020).

Statistics Sweden (2018a) "Invandring till Sverige 2017 och 2016 efter de 20 vanligaste födelseländerna”, http://www.scb.se/contentassets/0718e963391b4e0a98079c78acb 7723b/be0101-invandring-2017.xlsx (Accessed 5 November 2020).

Statistics Sweden (2018b) "Children and young persons aged 0-21 with Swedish and foreign background by sex and age. Year 2002-2016", http://www. statistiksdatabasen.scb.se/pxweb/en/ssd/START_LE_LE0102_LE0102A/ LE0102T15/?rxid=e41e2320-58a9-416e-a128-6f4241e3b093 (Accessed 15 July 2019).

Statistics Sweden (2018c) “Summary of population statistics 1960-2017”, https://www.scb. se/en/finding-statistics/statistics-by-subject-area/population/population-composition/ population-statistics/pong/tables-and-graphs/yearly-statistics - the-whole- country/ summary-of-population-statistics/ (Accessed 15 July 2019).

Statistics Sweden (2019) "Most immigrants were Swedish-born persons", https://www.scb.se/en/finding-statistics/statistics-by-subject-area/population/ population-composition/population-statistics/pong/statistical-news/populationstatistics-januaryjune-2019/ (Accessed 5 November 2020).

Swedish Migration Agency (2020) "History", https:/www.migrationsverket.se/English/About-the-Migration-Agency/Migration-to-Sweden/History.html (Accessed 5 November 2020).

Swedish Research Council (2019) "Are sex and gender perspectives relevant in your research?", https://www.vr.se/english/just-now/news/news-archive/2018-12-14-aresex-and-gender-perspectives-relevant-in-your-research.html (Accessed 6 December 2020).

Trondman, M. (2006) "Disowning knowledge: To be or not to be 'the immigrant' in Sweden”, Ethnic and Racial Studies 29 (3):431-451. https://doi. org/10.1080/01419870600597859

Trygged, S. \& E. Righard (Eds.) (2019) Inequalities and migration: Challenges for the Swedish welfare state. Lund: Studentlitteratur.

Voyer, A.M. (2016) "Betydelsen av etnisk bakgrund", 337-359 in A. Lund \& S. Lund (Eds.) Skolframgång $i$ det mångkulturella samhället. Lund: Studentlitteratur.

Voyer, A.M. (2018) “'If the students don't come, or if they don't finish, we don't get the money': Principals, immigration, and the organisational logic of school choice in Sweden”, Ethnography and Education 14 (4):448-464. https://doi.org/10.1080/1 7457823.2018 .1445540

Wacquant, L. (2005) "Race as civic felony", International Social Science Journal 57 (183):127-142. https://doi.org/10.1111/j.0020-8701.2005.00536.x

Wacquant, L. (2008) Urban outcasts: A comparative sociology of advanced marginality. Cambridge: Polity. 
Wimmer, A. (2015) "Race-centrism: A critique and a research agenda", Ethnic and Racial Studies 38 (13):2186-2205. https://doi.org/10.1080/01419870.2015.1058510 Winant, H. (2000) "Race and race theory", Annual Review of Sociology 26 (1):169-185. Winant, H. (2001) The World is a ghetto: Race and democracy since World War II. London: Basic Books.

Wooten, M. \& L. Couloute (2017) "The production of racial inequality within and among organizations", Sociology Compass 11 (1): e12446. https://doi.org/10.1111/ soc4.12446

Ålund, A. (1985) Skyddsmurar: Etnicitet och klass i invandrarsammanhang. Stockholm: Liber.

Ålund, A. (1988) "Invandrarkvinnor och problemideologier: Om möjligheter och begränsningar i den privata och offentliga sfären”, Sociologisk Forskning 25 (1): 32-46. Ålund, A. (1997) Multikultiungdom: Kön, etnicitet, identitet. Lund: Studentlitteratur.

\section{Authors}

Andrea Voyer is an Associate Professor (docent) at the Department of Sociology, Stockholm University. Voyer is a cultural sociologist whose research focuses on meaning and its impact on processes of social inclusion and exclusion on the basis of immigration, race, and class. She uses qualitative and computational sociological methods in her research.

Anna Lund is a professor of sociology and deputy head of the Department of Sociology, Stockholm University. Cultural sociological perspectives and ethnographic methods characterize her research, as well as a theoretical concern with social change and cultural transformation under conditions of adversity. Her current research interest is connected to how modes of incorporation is performed in school settings among and for migrant students as well as in Swedish children's theater. She employs civil sphere theory at the microlevel by investigating interactional and organizational processes in school and theater contexts.

\section{Corresponding author}

Andrea Voyer

Department of Sociology

Stockholm University, 10691 Stockholm

andrea.voyer@sociology.su.se 